\title{
Congenital nephrotic syndrome of Finnish type
}

\author{
Study of 75 patients
}

\author{
NIILO-PEKKA HUTTUNEN \\ From the Children's Hospital, University of Helsinki, Finland
}

\begin{abstract}
Huttunen, N-P. (1976). Archives of Disease in Childhood, 51, 344. Congenital nephrotic syndrome of Finnish type: study of 75 patients. Seventy-five patients with congenital nephrotic syndrome of Finnish type were identified in Finland in the period 1965-1973, giving an incidence of $12 \cdot 2 / 10^{5}$. A large placenta and proteinuria from birth are the hallmarks of the disease.

About one-quarter of the patients had oedema and/or abdominal distension at birth and in all cases the full nephrotic syndrome was documented before 2 months. More than half of the patients died before 6 months and none lived longer than 2 years 3 months. A slight rise in blood urea nitrogen or serum creatinine levels occurred in 14 cases, but in none of these did a frank uraemia develop before death. Infection appeared to be the immediate cause of death in $31 \%$ of the cases; in $43 \%$ no cause of death other than congenital nephrotic syndrome could be shown. Thrombi in large vessels were found in 11 out of 58 necropsies.
\end{abstract}

Congenital nephrotic syndrome of Finnish type (CNF) is a distinct disease entity characterized at birth by a large placenta and subsequently by early onset of symptoms, complete resistance to steroids, and death, usually within the first 2 years of life (Hallman, Norio, and Rapola, 1973; Norio, 1974). The disease is inherited as an autosomal recessive trait, and is exceptionally common in Finland, where the incidence has been estimated to be about 1 in 10000 births (Norio, 1966). The purpose of this investigation was to determine the frequency of the principal clinical signs in CNF, the cause of death, and the precise incidence of this disease in Finland.

\section{Patients and methods}

All known patients with CNF born in Finland from the beginning of 1965 to the end of 1973 , were included in the study. Since this disease was first defined (Hallman, Hjelt, and Ahvenainen, 1956), a list of the new cases of CNF occurring in Finland has been maintained at the Children's Hospital, University of Helsinki. Some patients were included retrospectively when a second child with CNF was born into a family. Most subjects were assembled from the above list, but some were identified from a review of death certificates at the Central Statistical Office of Finland for the years 19651973.

Diagnosis of CNF was based on a large placenta,

Received 28 July 1975. massive proteinuria, early onset of oedema, and a typical course of the disease. In $89 \%$ of the patients studied histological examination of renal tissue obtained by biopsy or at necropsy confirmed the diagnosis (Rapola and Savilahti, 1971). The data presented here are based on hospital and necropsy records. Urine analyses and determinations of blood urea nitrogen or serum creatine levels were performed by standard methods.

The control subjects were 983 infants, of known gestational age, born consecutively in the obstetrical ward of Hyvinkää District Hospital during 1971 and 1972.

\section{Results}

During the years $1965-1973$ a total of 75 patients in 12 hospitals were diagnosed as having CNF. The number of infants born alive in Finland during the corresponding years was 614932 (Central Statistical Office of Finland, 1976). Based on these figures the incidence of CNF in Finland is $12 \cdot 2 / 10^{5}$, or nearly 1 in 8200 births. Fig. 1 gives the gestational ages of CNF patients and control subjects, and Fig. 2 the birthweights and body lengths. Every newborn whose gestational age ranged from 33-37 weeks, every 5th newborn whose gestational age was 38 weeks, and every 10th newborn whose gestational age was 39 or 40 weeks were included in the group of controls presented in Fig. 2. Birthweights were available for all of these 158 control newborns, and body lengths for all but 2 . 


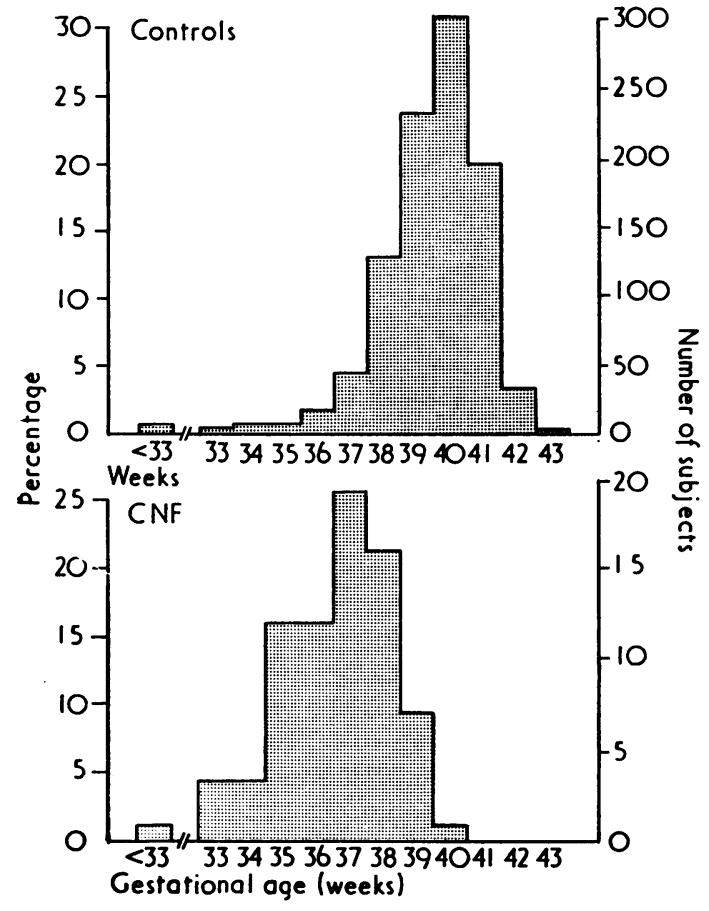

Fig. 1.-Gestational ages of 983 control subjects and 74 CNF infants.

One CNF patient with a gestational age of 29 weeks and another whose gestational age was unknown were excluded from the group of CNF patients in Fig. 2. Body length measurements were available for 68 of the 73 CNF patients.

There is a clear tendency for patients with CNF to be born prematurely. In addition, CNF patients tended to be both lighter and shorter at birth than control subjects of equal gestational age, with the difference in size becoming more pronounced towards term. The mean ratio of placental/fetal weight of CNF patients was $0 \cdot 43$, range $0 \cdot 20-0 \cdot 65$. In all CNF patients except one the ratio of placental/ fetal weight was more than $0 \cdot 25$. Placental/ fetal weight ratios, Apgar scores, frequency of meconium-stained fetal fluid, and frequency of breech presentation of patients and control subjects are presented in Table $\mathrm{I}$. CNF infants differed significantly from control infants of the same gestational age $(P<0.001)$ for placental/fetal ratio (t-test), frequency of meconium-stained fetal fluid, and frequency of low Apgar scores ( $x^{2}$ test). The number of breech presentations among CNF patients whose gestational age was 36 weeks or less was 4 out of 31 and among those whose gestational age
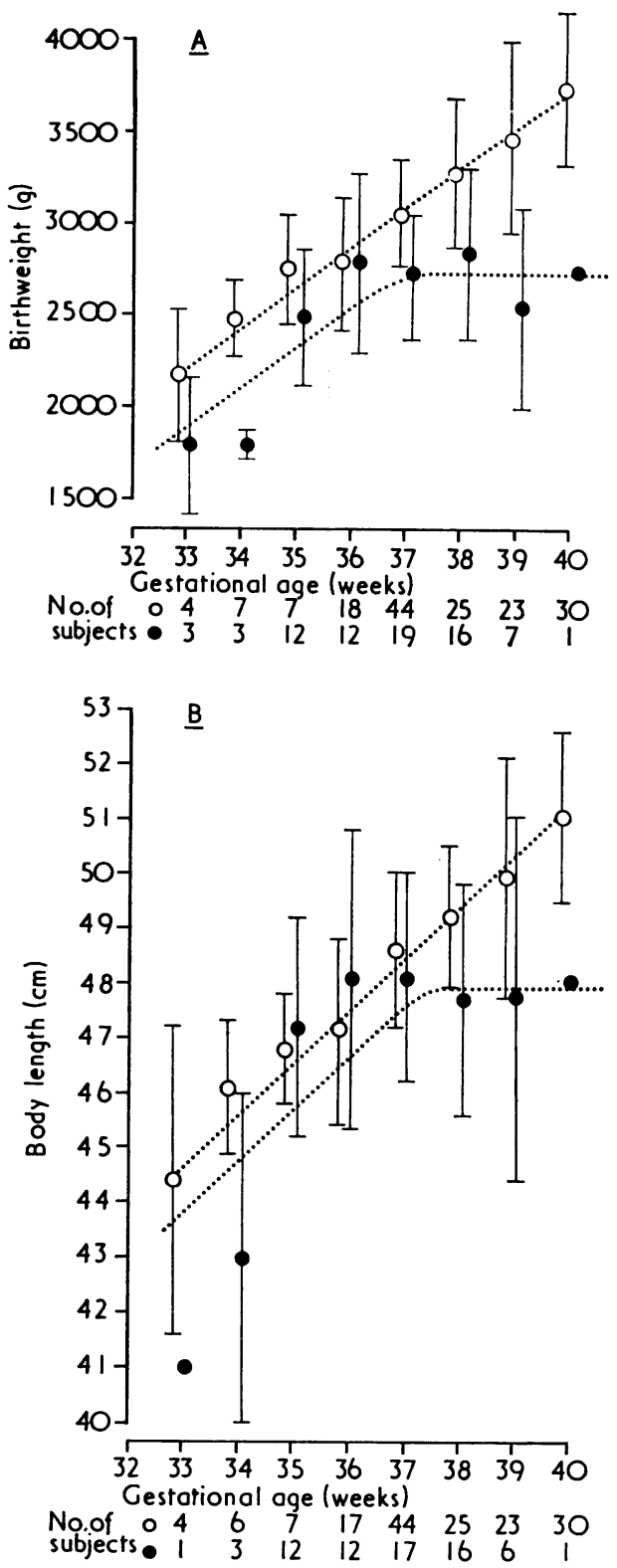

Fig. 2.- $(A)$ Weights and $(B)$ lengths at birth of $C N F$ infants $(\odot)$ and controls $(O)$. Vertical lines indicate $1 S D$. The number of subjects in each group is shown.

was 37 weeks or more, 5 out of 43 . When compared with the number of breech presentations among control infants of corresponding gestational age these frequencies were significant $(P<0.05$ and $\mathrm{P}<0 \cdot 001$, respectively; and $x^{2}$ test). 
TABLE I

Ratio of placental ${ }^{\star} /$ fetal weight, frequency of breech presentation, frequency of meconium-stained fetal fluid, and Apgar scores of CNF infants and controls

\begin{tabular}{|c|c|c|c|c|c|c|c|c|c|c|c|c|c|}
\hline & \multirow{2}{*}{\multicolumn{3}{|c|}{$\begin{array}{c}\text { Placental/fetal } \\
\text { weight }\end{array}$}} & \multirow{2}{*}{\multicolumn{2}{|c|}{$\begin{array}{l}\text { Frequency of } \\
\text { breech } \\
\text { presentation }\end{array}$}} & \multirow{2}{*}{\multicolumn{2}{|c|}{$\begin{array}{l}\text { Frequency of } \\
\text { meconium- } \\
\text { stained } \\
\text { fetal fluid }\end{array}$}} & \multirow{2}{*}{\multicolumn{2}{|c|}{6}} & \multicolumn{4}{|c|}{ 1-minute Apgar score } \\
\hline & & & & & & & & & & $7-8$ & & \multicolumn{2}{|c|}{$9-10$} \\
\hline & No. & Mean & SD & No. & $\%$ & No. & $\%$ & No. & $\%$ & No. & $\%$ & No. & $\%$ \\
\hline $\begin{array}{l}\text { CNF infants } \\
\text { Controls }\end{array}$ & $\begin{array}{r}74 \\
980\end{array}$ & $\begin{array}{l}0 \cdot 43 \\
0 \cdot 18\end{array}$ & $\begin{array}{l}0.01 \\
0.03\end{array}$ & $\begin{array}{l}12 / 74 \\
25 / 983\end{array}$ & $\begin{array}{r}16 \\
3\end{array}$ & $\begin{array}{c}49 / 66 \\
128 / 938\end{array}$ & $\begin{array}{l}74 \\
14\end{array}$ & $\begin{array}{r}11 / 74 \\
14 / 983\end{array}$ & $\begin{array}{r}15 \\
1\end{array}$ & $\begin{array}{c}30 / 74 \\
160 / 983\end{array}$ & $\begin{array}{l}40 \\
16\end{array}$ & $\begin{array}{c}33 / 74 \\
809 / 983\end{array}$ & $\begin{array}{l}45 \\
82\end{array}$ \\
\hline
\end{tabular}

* The placentas were weighted with fetal membranes and a short stump of umbilical cord.

Proteinuria occurred in all but one patient from the time of the first urine sample (Table II). The time of onset of oedema or abdominal distension was noted in $61 \mathrm{CNF}$ patients (Table II), either or both occurring during the first week of life in 32, during the first month in 55, and in none later than 2 months of age. The exact time of and reason for the first admission to a paediatric ward was known in 69 cases (Table III). (1) Asphyxia or prematurity during the first day of life in 23 out of 33 cases, and later in only 4 out of 36 . (2) Oedema or abdominal distension during the first day of life in 4 out of 33 cases, and later in 15 out of 36 . (3) A large placenta, proteinuria, or definitive diagnosis of CNF in 15 .

Information about the blood urea nitrogen (BUN) or serum creatinine levels was available for 50 CNF patients. Slightly raised levels of BUN occurred in 8 patients (range $23-57 \mathrm{mg} / 100 \mathrm{ml}$ ) and of serum creatinine in 6 (range $0 \cdot 8-3 \cdot 0 \mathrm{mg} / 100 \mathrm{ml}$ ). In none, however, was a uraemic syndrome documented.

All CNF patients died during the observation period. Length of survival is shown in Fig. 3. Mean survival for the 75 patients was 7.6 months. The oldest patient was aged 2 years 2 months 10 days at death. At necropsy, thrombosis of the inferior vena cava was found in 7 cases, of sagittal sinus in 1 , of cerebral vein in 1, and of right atrium in 1 . In addition, 1 patient died of a pulmonary embolism that had originated from the right atrium. Severe thromboembolic complications were found in a total of 11 out of 58 necropsies. Cause of death of CNF patients is shown in Table IV. Infection was considered to be the cause of death in 23 cases, renal transplantation in 9, thrombotic complications in 4, and other definable causes in 7. Death could be attributed to no definable cause other than $\mathrm{CNF}$ in 32 cases.

\section{Discussion}

Taking into account all previously published cases (Norio, 1966; Hallman, Norio, and Kouvalainen, 1967) plus the cases in the present study in which the period of investigation extended through 1973, a total of $151 \mathrm{CNF}$ patients from 119 families have been identified in Finland. The incidence of CNF based on the results of the present study, ie., 1 in 8200 births, is higher than than that estimated by Norio (1966). The awareness of Finnish physicians of this disease has certainly improved during the last 10 years. Nevertheless, though the clinical

TABLE II

Time of documentation of proteinuria and onset of oedema and/or abdominal distension in CNF infants

\begin{tabular}{|c|c|c|c|c|}
\hline \multirow{2}{*}{ Time } & \multicolumn{2}{|c|}{$\begin{array}{c}\text { Documentation of } \\
\text { proteinuria }\end{array}$} & \multicolumn{2}{|c|}{$\begin{array}{l}\text { Onset of oedema and/or } \\
\text { abdominal distension }\end{array}$} \\
\hline & No. of cases & $\begin{array}{c}\text { Cumulative } \\
\%\end{array}$ & No. of cases & $\underset{\%}{\text { Cumulative }}$ \\
\hline $\begin{array}{l}\text { At birth } \\
\text { During first week of life } \\
\text { During first month of life } \\
\text { During second month of life }\end{array}$ & $\begin{array}{c}14 \\
39 \\
13^{\star} \\
9\end{array}$ & $\begin{array}{c}19 \\
71 \\
88 \\
100\end{array}$ & $\begin{array}{r}16 \\
16 \\
23 \\
6\end{array}$ & $\begin{array}{r}26 \\
52 \\
90 \\
100\end{array}$ \\
\hline Total & 75 & & 61 & \\
\hline
\end{tabular}

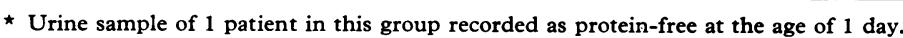


TABLE III

Time of and principal reason for first hospital admission of 69 CNF infants

\begin{tabular}{|c|c|c|c|c|c|c|c|c|}
\hline \multirow{2}{*}{ Reason for admission } & \multicolumn{2}{|c|}{ 1st day } & \multicolumn{2}{|c|}{ 2nd to 7 th day } & \multicolumn{2}{|c|}{ After 7 th day } & \multicolumn{2}{|c|}{ Total } \\
\hline & No. & $\%$ & No. & $\%$ & No. & $\%$ & No. & $\%$ \\
\hline Total & 33 & 48 & 17 & 25 & 19 & 27 & 69 & 100 \\
\hline
\end{tabular}

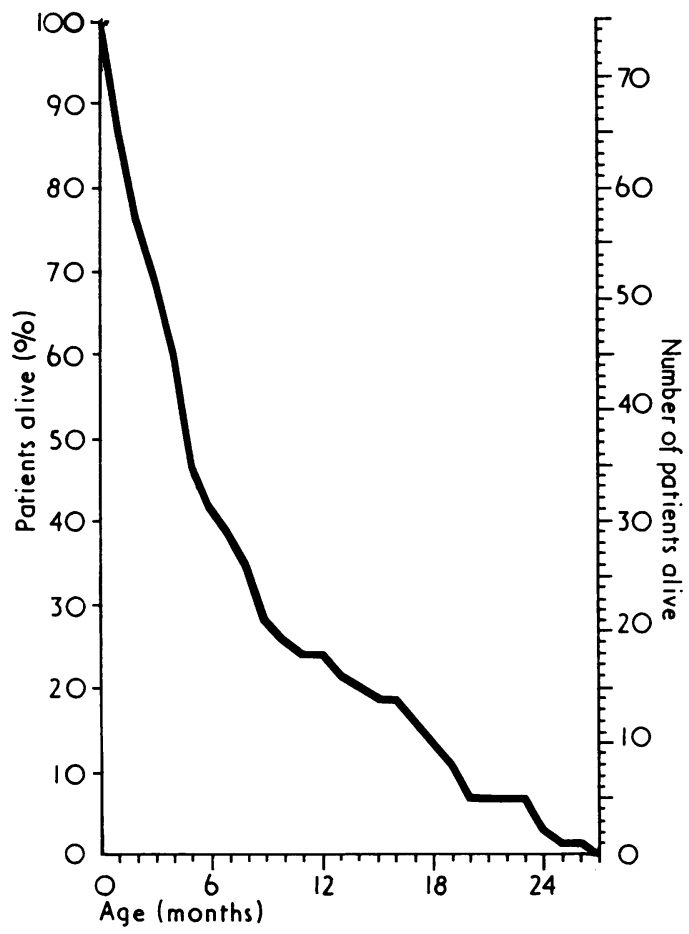

FIG. 3.-Length of survival of 75 CNF infants

features are extremely characteristic and the illness is easy to diagnose at a few weeks of age, even now some patients with CNF undoubtedly die during the first days of life from asphyxia or other neonatal complications without CNF having been diagnosed. Hence the estimated incidence may be slightly low.

An uncommonly large placenta is the most prominent sign of CNF at birth and has been emphasized in earlier studies (Kouvalainen, Hjelt, and Hallman, 1962; Hallman et al., 1970; Hallman et al., 1973). In one case in the present series the ratio of placental

\section{TABLE IV}

Immediate cause of death of CNF patients. Diagnosis is based on clinical and necropsy findings in 58 cases and on clinical findings alone in 17

\begin{tabular}{|c|c|c|}
\hline Cause of death & No. of cases & $\%$ \\
\hline $\begin{array}{l}\text { Infection } \\
\text { Sepsis } \\
\text { Pneumonia } \\
\text { Peritonitis } \\
\text { Meningitis } \\
\text { Other } \\
\text { Transplantation trial } \\
\text { Thrombotic complication } \\
\text { Cerebral vein thrombosis } \\
\text { Pulmonary artery thrombosis } \\
\text { Pulmonary embolism } \\
\text { Sagittal sinus thrombosis } \\
\text { Miscellaneous } \\
\text { Aspiration } \\
\text { Cerebral haemorrhage } \\
\text { Interstitial occlusion } \\
\text { Kernicterus } \\
\text { Pulmonary haemorrhage } \\
\text { Pulmonary atelectasis } \\
\text { Subarachnoid haemorrhage } \\
\text { CNF alone }\end{array}$ & $\begin{array}{l}1 \\
1 \\
1 \\
1 \\
1 \\
1 \\
1 \\
1 \\
1 \\
1 \\
1\end{array}$ & $\begin{array}{r}12 \\
5\end{array}$ \\
\hline Total & 75 & 100 \\
\hline
\end{tabular}

/fetal weight was less than $0 \cdot 25$. This lightest placenta belonged to a twin who had a healthy twin sister whose ratio of placental/fetal weight was recorded as 0.22 . It is possible that the placentas of the twins were exchanged by mistake at delivery. If this highly likely error were corrected, the ratio of placental/fetal weight of the CNF twin would be $0 \cdot 27$. A large placenta accompanied by retarded intrauterine growth, and frequently by signs of prenatal asphyxia indicate that CNF is a congenital disease that begins in utero. The recording of one protein-free urine sample in the present series was almost certainly an error because there is good evidence that in both proteinuria (Seppälä and Ruoslahti, 1972) and severe hypoproteinaemia (Kouvalainen, 1963) onset occurs before 
birth. No good explanation can be given for the abnormally high frequency of breech presentation, but it is supposed that the large placenta interferes with normal intrauterine movements of the fetus (Hallman et al., 1970).

Pre- and postnatal asphyxia, probably caused by defective function of the oedematous placenta, is a frequent finding in CNF. Asphyxia and prematurity are the most frequent causes for admission to paediatric wards immediately after birth; symptoms of the nephrotic syndrome are the main reasons for admission after the postnatal period. Either oedema or abdominal distension brought on by ascites or by meteoristic bowel were already present in one-quarter of the patients at birth, and in no patient was the full nephrotic syndrome noted later than the age of 2 months. By a few months of age the oedema often disappears and the children then tend to be dystrophic, though the abdominal distension usually persists (Hallman et al., 1970).

Length of survival of CNF patients has remained practically unchanged since 1965 (Hallman et al., 1970). In the present series more than half of the infants had died by 6 months and none reached the age of $2 \frac{1}{2}$ years. Nearly $19 \%$ of the necropsies on CNF patients showed either a venous or arterial thrombosis. A tendency towards thrombosis has also been observed in other types of nephrotic syndrome (Levin, Zamit, and Schmaman 1967; Lewy and Wellington, 1974). The hypothesis that steroid therapy might be an aetiological factor in thrombosis (Lieberman et al., 1968; Mukherjee et al., 1970) receives no support here, because none of the CNF patients with thrombotic complications had been given steroids. Hypovolaemia and an increased incidence of sepsis (Lieberman et al., 1968) together with disturbances in coagulation (Lange et al., 1974) or in fibrinolysis (Scheinman and Stiehm, 1971) are probably the factors which predispose patients to the formation of intravascular thrombi, in both CNF and other types of nephrotic syndrome.

Infections or other definitive causes of death could be documented in about one-half of the CNF patients, whereas in the remainder only CNF could be shown. Though a slight rise of BUN or serum creatinine levels was noted in 14 cases, in none of these could a frank uraemic syndrome be considered as the immediate cause of death. Presumably, massive and continuous protein leakage produces a a state of severe protein depletion and weakened bodily defences, so that sudden death may leave no detectable signs for the pathologist except those of CNF itself.

I am indebted to Prof. Niilo Hallman and to Dr. Reijo Norio for valuable discussions, and to Mrs RiittaLiisa Lönnqvist and Miss Kirsti Erjamo for collection of the original documents. This study was supported by a grant from the Sigrid Jusélius Foundation, Finland.

\section{REFERENCES}

Central Statistical Office of Finland. (1976). Statistical Yearbouk of Finland 1975. Helsinki.

Hallman, N., Hjelt, L., and Ahvenainen, E. K. (1956). Nephrotic Syndrome in newborn and young infants. Annales Paediatriae Fenniae, 2, 227.

Hallman, N., Norio, R., and Kouvalainen, K. (1967). Main features of the congenital nephrotic syndrome. Acta Paediatrica Scandinavica, Suppl. 172, 75 .

Hallman, N., Norio, R., Kouvalainen, K., Vilska, J., and Kojo, N. (1970). Das kongenitale nephrotische Syndrom. Ergebnisse der inneren Medizin und Kinderheilkunde, 30, 3.

Hallman, N., Norio, R., and Rapola, J. (1973). Congenital nephrotic syndrome. Nephron, 11, 101.

Kouvalainen, K. (1963). Immunological features in the congenital nephrotic syndrome. A clinical and experimental study. $A n-$ nales Paediatriae Fenniae, 9, Suppl. 22.

Kouvalainen, K., Hjelt, L., and Hallman, N. (1962). Placenta in congenital nephrotic syndrome. Annales Paediatriae Fenniae, 8,181 .

Lange, L. G., Carvalho, A., Bagdasarian, A., Lahiri, B., and Colman, R. W. (1974). Activation of Hageman factor in the nephrotic syndrome. American fournal of Medicine, 56, 565.

Levin, S. E., Zamit, R., and Schmaman, A. (1967). Thrombosis of pulmonary arteries and the nephrotic syndrome. British Medical fournal, 1, 153.

Lewy, P. R., and Wellington, J. (1974). Nephrotic syndrome in association with renal vein thrombosis in infancy. fournal of Pediatrics, 85, 359.

Lieberman, E., Heuser, E., Gilchrist, G. S., Donnell, G. N., and Landing, B. H. (1968). Thrombosis, nephrosis and corticosteroid therapy. Fournal of Pediatrics, 73, 320.

Mukherjee, A. P., Toh, B. H., Chan, G. L., Lau, K. S., and White, J. C. (1970). Vascular complications in nephrotic syndrome: relationship to steroid therapy and accelerated thromboplastin generation. British Medical fournal, 4, 273.

Norio, R. (1966). Heredity in the congenital nephrotic syndrome. Annales Paediatriae Fenniae, 12, Suppl. 27.

Norio, R. (1974). Congenital nephrotic syndrome of Finnish type and other types of early familial nephrotic syndromes. Birth Defects. Original Articles Series, Vol. 10, p.69. National Foundation, Johns Hopkins University Press, London.

Rapola, J., and Savilahti, E. (1971). Immunofluorescent and morphological studies in congenital nephrotic syndrome. Acto Paediatrica Scandinavica, 60, 253.

Scheinman, J. I., and Stiehm, E. R. (1971). Fibrinolytic studies in the nephrotic syndrome. Pediatric Research, 5, 206.

Seppalä, M., and Ruoslahti, E. (1972). Alpha fetoprotein in amniotic fluid: an index of gestational age. American fournal of Obstetrics and Gynecology, 114, 595.

Correspondence to Dr. N.-P. Huttunen, Children's Hospital, University of Helsinki, Stenbäckinkatu 11, SF-00290 Helsinki 29, Finland. 